\title{
Cosmic Democracy or Cosmic Monarchy? Empedocles in Plato's Statesman
}

\author{
Cameron F. Coates \\ DePaul University, Department of Philosophy, $235^{2}$ N. Clifton Ave. Suite 150, \\ Chicago, IL 6o614, USA \\ ccoates@depaul.edu
}

\begin{abstract}
Plato's references to Empedocles in the myth of the Statesman perform a crucial role in the overarching political argument of the dialogue. Empedocles conceives of the cosmos as structured like a democracy, where the constituent powers 'rule in turn', sharing the offices of rulership equally via a cyclical exchange of power. In a complex act of philosophical appropriation, Plato takes up Empedocles' cosmic cycles of rule in order to 'correct' them: instead of a democracy in which rule is shared cyclically amongst equal constituents, Plato's cosmos undergoes cycles of the presence and absence of a single cosmic monarch who possesses 'kingly epistèmè'. By means of a revision of Empedocles' democratic cosmology, Plato's richly woven myth is designed precisely to reject the appropriateness of democracy as a form of human political association and legitimate monarchy in its stead.
\end{abstract}

\section{Keywords}

cosmology - democracy - Empedocles - monarchy - myth - Plato - ruling in turn - Statesman

Near the beginning of Plato's Statesman, the Stranger relates to Young Socrates a wonderful and perplexing cosmological myth (268d-274e). The world, the Stranger contends, alternates perpetually between two cosmic ages: one is a Hesiodic 'Golden Age' of harmony, plenty, and divine protection; the other is their own degenerate age, in which the care of gods is absent and they are exposed to all the typical pains and struggles of human life. The myth is 
complete with fantastic images of autochthonous human generation, aging in reverse, and a demiurgic 'shepherd' god who will return to save the world on the verge of its destruction. In a recent treatment of this passage by Charles Kahn, Kahn observes that the myth is remarkable not only for the richness of its images but also for the particular function it serves in the dialogue. While most Platonic myths function as a 'postscript to the argument proper', the Statesman myth (like the myth in the Phaedrus) is laid out towards the beginning of the dialogue and 'seems to provide a premise for the following argument'.' For Kahn, the myths of the Phaedrus and Statesman are 'genuine' myths because they both 'require a certain suspension of disbelief, since the fantastic story they tell makes a doctrinal contribution to the theory that follows.' In other words, the myth of the two ages offers a specific kind of support for the political argument of the dialogue, one that is allusive and persuasive rather than strictly argumentative.

In this paper I explore how Plato's engagement with the philosophy of Empedocles informs the function of the Statesman myth. Many commentators have noted that the myth comprises a richly woven fabric of elements drawn from and inspired by diverse traditions, including the Homeric, Hesiodic, and Presocratic philosophic traditions. Mitchell Miller has given insightful analysis of the way in which Plato comments on the Homeric trope of the 'shepherd of the people' and its development in the tradition of sophistic humanism. ${ }^{3}$ More recently, Helen van Noorden has given a thorough analysis of Plato's integration of Hesiodic elements into the myth. ${ }^{4}$ Likewise, Joseph B. Skemp, Kahn, and van Noorden cite Empedocles' cosmic cycles as a relevant precursor to the myth. ${ }^{5}$ The import of the Homeric and Hesiodic references in the myth has been treated quite extensively by Miller and van Noorden, respectively. However, despite the widely recognized reference to Empedocles in the myth, there has been no extended examination of the philosophical relevance of this reference to the dialogue as a whole. I argue that the Empedocles reference

1 C. H. Kahn, Plato and the Post-Socratic Dialogue: The Return to the Philosophy of Nature (Cambridge, U.K: Cambridge University Press, 2013), p. 220. The logical terminology of 'premise' is perhaps a little misleading, especially in light of the complex relationship between muthos and logos as forms of discourse in Plato's thought. My interpretation of the function of the myth in the dialogue comprises Section 3 of this article.

2 Kahn, Plato and the Post-Socratic Dialogue, p. 220.

3 M. H. Miller, The Philosopher in Plato's Statesman (The Hague: Martinus Nijhoff Publishers, 1980), pp. 40-53.

4 H. van Noorden, Playing Hesiod:The 'Myth of the Races' in Classical Antiquity (Cambridge, U.K.: Cambridge University Press, 2015), pp. 142-67.

5 J. B. Skemp, Plato's Statesman (New Haven:Yale University Press, 1952), p. 9o. Kahn, Plato and the Post-Socratic Dialogue, pp. 222, 224. Van Noorden, Playing Hesiod, pp. 152-3. 
develops a particular political theme in the dialogue. Plato's political project in the Statesman is informed by the Greek philosophic tradition of considering human political relations to be grounded in the very structure of the cosmos (which itself can only be understood in the conceptual terms of human politics). ${ }^{6}$ I suggest that the myth of the two ages offers Plato's take on this Presocratic trope. Empedocles could represent for Plato a paradigm of this tradition, for he portrays the cosmos as structured like a democracy. In the Statesman, Plato replaces Empedocles' cosmic democracy with a cosmic sovereign monarchy. He does so by emphatically inverting Empedocles' own model of alternating cycles of cosmic rule, replacing the cyclically shared rulership of Empedocles' cosmology with cycles of the presence and absence of a single cosmic monarch. Playing on the trope of a macro-micro level similarity between cosmos and polis, Plato rejects democracy and legitimates monarchic sovereignty in the human political sphere precisely by rejecting Empedocles' cosmic democracy and establishing his own cosmic monarchy in its stead. The Empedoclean reference in the Statesman thus performs an integral function in the overarching political argument of the dialogue. I first show how Plato's reference to Empedocles forms the basic structure of his own cosmological myth. Next I demonstrate how a careful reading of Empedocles' fragments reveals his commitment to thinking of the cosmos as democratically structured, and I suggest that Plato read Empedocles' cosmology as having a distinctly democratic resonance. Finally, I illustrate how Plato's complex appropriation of Empedocles' cosmic cycles undergirds the overarching political argument of the dialogue: by forcefully rejecting cosmic democracy in favor of cosmic monarchy, the Stranger is able to establish sovereign epistēme as the touchstone in the search for the true statesman and thereby reject the legitimacy of non-monarchic forms of rule.

\section{The Empedoclean Reference in the Myth}

A discussion in the Sophist reveals that Empedocles is already on the radar for the Stranger prior to the transition to the Statesman. Following the famous 'parricide' of Parmenides (241d-242b), the Stranger claims that previous

6 This tradition can be traced back to the earliest extant fragments of Greek philosophy: e.g., in Anaximander's fragment $\mathrm{B}$, where fundamental cosmic processes are understood through the normative concept of retributive justice. Cf. Vlastos' illuminating treatment of this philosophic trope in G. Vlastos, 'Equality and Justice in Early Greek Cosmologies', Classical Philology vol. 42, no. 3 (July, 1947), pp. 156-178. Cf. esp. Vlastos' treatment of Anaximander at pp. 168-73. I discuss Vlastos' analysis of Empedocles below. 
philosophers have discussed Being 'carelessly', for they never really specified 'just how many beings there are and what they're like' (242c). ${ }^{7}$ In the following discussion of this philosophic tradition, the Stranger refers to 'some Ionian and Sicilian muses' (242d) (namely, Heraclitus and Empedocles, respectively) who tried to 'weave together' ontological monism and pluralism, claiming that 'that which is is both many and one' (242d-e). While the Stranger interprets Heraclitus as holding the doctrine that Being is somehow 'always' (and therefore simultaneously) one and many, ${ }^{8}$ he interprets Empedocles as claiming that Being alternates between states of oneness and manyness: 'The softer ones [i.e., Empedocles and his students] relaxed this [claim] that these things always are this way; they say that the All, in turn ( $\left.\varepsilon^{2} \nu \mu \dot{\varepsilon} p \varepsilon l\right)$, is at one time ( it is itself warlike with itself on account of some strife' (242e-243a; my trans. Cp. 252b1-6). Here the Stranger refers to Empedocles' cosmic model, in which Love and Strife (and concurrently, the different elements) rule in turn ('ंv $\mu \varepsilon \dot{\varepsilon} \varepsilon \varepsilon$

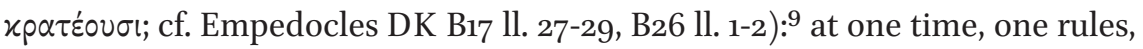

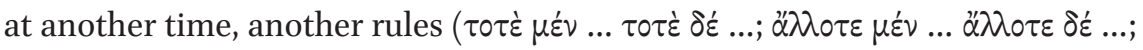
cf. B17 ll. 1-2, B17 ll. 7-8, B26 ll. 5-6). It is precisely this model of cosmic cycles of rule that will form the foundation of the Stranger's myth of the two ages in the Statesmen. Similarly to the Stranger's 'parricidal' rejection of Parmenides' ontology, however, Empedocles' cosmic model will be taken up only to be altered fundamentally.

Turning now to the Statesman myth itself, we can begin by noting that many commentators have identified Empedocles as the primary inspiration for the cosmic cycles of the Statesman myth. In Skemp's commentary, Skemp discusses a wide variety of possible sources for the myth, including Herodotean historical accounts of Egypt, Pythagorean doctrines, Eudemus' theo-cosmogony, Zoroastrian doctrines (including the cosmogonical myth of Oromazes and Areimanius found in Plutarch's Isis and Osiris 47), and other Iranian influences

7 All translations from the Sophist, except where noted, are from N. P. White's translation in J. M. Cooper and D. S. Hutchinson, Plato: Complete Works (Indianapolis: Hackett Publishing, 1997).

8 Here the Stranger states (loosely paraphrasing Heraclitus DK B51): 'for being taken apart,

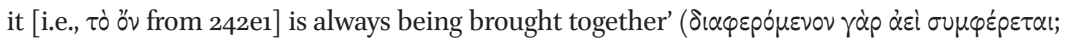
my trans.). I take it that the Stranger modifies the original aphorism to stress his interpretation that Heraclitus' position maintains the simultaneous oneness and manyness of Being.

9 Unless otherwise noted, all line number references, Greek text, and translations from the fragments of Empedocles are from D. W. Graham, The Texts of Early Greek Philosophy: The Complete Fragments and Selected Testimonies of the Major Presocratics, vol. 1 (Cambridge, U.K.: Cambridge University Press, 2010). 
introduced to the Greek world through Greco-Iranian syncretism..$^{10}$ Ultimately, however, Skemp opts for Empedocles as the most relevant inspiration for the myth's cosmic cycles. ${ }^{11}$ Kahn remarks that 'the Empedoclean parallel determines the general form of the myth': while the Statesman myth certainly draws from many diverse sources, '... the central, most original idea is Plato's adaptation of Empedoclean cosmic reversals to paint a picture of the age of Kronos in which the conditions of human life are radically reversed.12 Van Noorden reiterates this observation in her treatment of the Hesiodic background of the myth. She notes that Empedocles' cosmic cycles 'provide positive inspiration for the basic idea of the Elean [sic] Stranger's story' and suggests that interpreting the myth in light of its Empedoclean framework could solve some long-standing issues of interpretation for both cosmologies. ${ }^{13}$ Kahn emphasizes that these two cosmologies share the same fundamental structure of 'a symmetrical movement back and forth between diametrically opposed situations',

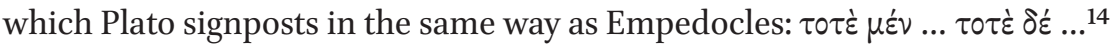

But how exactly do we see this shared cosmological structure in the texts? In Empedocles, the cosmos alternates between a state of absolute dissolution in which the elements are all completely separated from one another and a state of absolute conglomeration in which the elements are completely and homogeneously combined. ${ }^{15}$ This cycle of alternation is due to the fact that the

$10 \quad$ Skemp, Plato's Statesman, pp. 85-103.

11 Skemp, Plato's Statesman, pp. 94, 146 n. 1.

12 Kahn, Plato and the Post-Socratic Dialogue, pp. 222, 224, respectively.

13 Van Noorden, Playing Hesiod, p. 152. Namely, issues concerning the way in which both accounts interweave different (and potentially incompatible) kinds of discourse (e.g., in Plato, the rational-theological discourse of the 'god' and 'demiurge' versus the mythic discourse of 'Kronos' and 'Zeus'; in Empedocles, the physicalistic discourse of elements and their mixture versus the daemonic mythic discourse). Cf. Van Noorden, Playing Hesiod, 152-3 and the literature cited in her footnotes.

14 Kahn, Plato and the Post-Socratic Dialogue, p. 222. For Plato's signposting of the cosmic

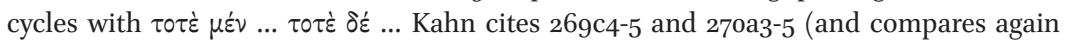
Sophist 242e5-243a1) to which we may add $270 \mathrm{~b}_{7}-8$, as well as the near match $274 \mathrm{~d} 8$ ( vôv

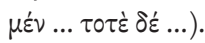

15 Precise descriptions of Empedocles' cosmic cycle are not found in the fragments and reconstruction of its details is difficult. There is much debate in the literature concerning even the basic features of the cosmic cycle. My characterization follows the interpretations of Graham, Inwood, O'Brien, and Wright: Graham, The Texts of Early Greek Philosophy, p. 426; B. Inwood, The Poem of Empedocles: A Text and Translation with Introduction by Brad Inwood (Toronto: University of Toronto Press, 1992), pp. 40-52; D. O'Brien, 'Empedocles' Cosmic Cycle', The Classical Quarterly 17, no. 1 (May, 1967), pp. 29-40; M. R. Wright, Empedocles: The Extant Fragments (New Haven: Yale University Press, 1981), pp. 164-74, 181-229. For the cosmic cycles generally, cf. B17, B26. For the state of homogeneous combination, cf. B27, B27a, B28, B29 and Wright ad loc. For evidence of 
deities of Love and Strife 'rule in turn' (B17 ln. 29, B26 ln. 1). When Strife rules the cosmos, there is a period of continually increasing disintegration until the cosmos reaches the condition of absolute dissolution. At this point Love takes over, and there is a period of continually increasing integration (B35, B36) until the condition of absolute conglomeration is reached, after which rule is again passed to Strife, and the cycle repeats. The phenomenal world of our experience is situated in one of the interim periods between these two extreme poles (cf. B21, B23, B26, B35). ${ }^{16}$ In Plato's myth, the cosmos undergoes a similar alternating cycle between the Age of Kronos and the Age of Zeus. During the Age of Kronos, the cosmos' rotation is guided by the demiurge (269c). This is a Hesiodic 'Golden Age' of profound harmony between humans, animals, and divinities during which the gods themselves care for all living creatures, the earth generates nourishment for us 'spontaneously' ( $\alpha \dot{\tau} \tau o \mu \dot{\alpha} \tau \eta)$, and there are no politeiai or traditional family structures $(271 \mathrm{c}-272 \mathrm{~b})$. During this time living beings age in reverse; they sprout from the earth fully grown, then become younger and younger until they finally disappear (270d-271c). After an appointed amount of time autochthonous generation is spent (for 'each soul had given up all her generations, having fallen into the ground as seed as many times as had been ordained for each') (272e), ${ }^{17}$ at which point the demiurge immediately lets go of the 'rudder' of the cosmos and he and the lesser divinities withdraw (272d-e). Now we enter the Age of Zeus, in which the cosmos, led by its own 'destiny and inborn desire' (272e), reverses directions and takes

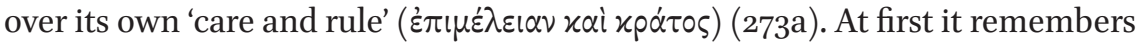
the 'teaching' of the demiurge and proceeds in an orderly fashion, but over time it slowly forgets these teachings, becoming more and more disordered and producing 'everything under the heavens that turns out to be harsh and unjust' (273a-c). Finally, when the cosmos has become so disordered that it is on the brink of complete destruction, the demiurge once again 'takes his seat at the helm' and restores order, bringing the cosmos back into the harmonious Age of Kronos, and once again 'fashions it into something immortal and ageless' (273d-e). In both authors' cosmologies we see a cosmos cyclically

the state of complete separation, we rely on Plutarch's The Face of the Moon 926d-927a and extrapolation from texts of Aristotle and Simplicius; cf. O'Brien's sensitive treatment of the evidence (O'Brien, 'Empedocles' Cosmic Cycle') as well as Inwood, The Poem of Empedocles, p. 49; Wright, Empedocles, pp. 185-6.

16 Cf. esp. Wright's discussion of B26: Wright, Empedocles, pp. 181-2.

17 Unless otherwise noted, all translations from the Statesman are from E. T. H. Brann, P. Kalkavage, and E. Salem, Plato Statesman: Translation, Introduction, Glossary, and Essay (Newburyport, MA: Focus Publishing, 2012). 
alternating between two opposed eras, one characterized broadly by harmony and friendship, the other characterized by disharmony and strife.

The Empedoclean allusions go deeper than this basic structural similarity, however. In a way analogous to Empedocles' era of increasing dissolution, the Age of Zeus is one in which the cosmos, gradually 'forgetting' the teachings

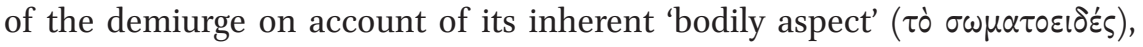

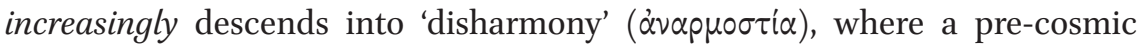

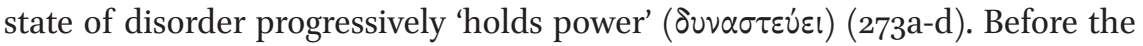
cosmos can reach a state analogous to Empedocles' condition of absolute dissolution, however, (i.e., before it can 'plunge into the boundless sea of unlikeness

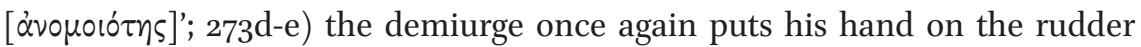
of the cosmos and reverses its rotation. While the Age of Kronos is presented by the Stranger as an era characterized by an unchanging condition of care and attention from the god rather than as a period of increasing integration, this age also shares some interesting similarities to Empedocles' era of Love. Both van Noorden and Kahn note that the harmony between animals and human beings during the Age of Kronos, during which 'no animal was wild or fodder for another, and there was no war among them nor any faction at all' (271e1-2), appears to refer directly to Empedocles B130, where, in a description of the time during Love's rule, we are told that animals '... were all tame and gentle towards men, both beasts and fowl, and friendly feelings radiated. ${ }^{18}$ Kahn further suggests that the cycle of reincarnation that takes place in the Age of Kronos (when 'the earthborn kind' were 'revived anew there out of those who had died and were lying in the earth'; 271a-b) and the 'fixed periods for rebirths at 272d6-e3' recall the cycles of the transmigration of souls in the Phaedrus, both Platonic myths referencing in part the exile and fixed series of reincarnations for the daimōn in Empedocles B115. ${ }^{19}$ Indeed, the Stranger's take on the mythic trope of autochthonous growth also has an antecedent in Empedocles' account of the generation of men and women from the earth (B62). ${ }^{20}$ Kahn further suggests that we find in the Statesman myth an early formulation of Plato's conception of the cosmos as a living and intelligent animal, which is to

18 Van Noorden, Playing Hesiod, p. 152; Kahn, Plato and the Post-Socratic Dialogue, p. 223. In specifying that no animal was 'food' or 'meat' ( $\dot{\delta} \delta \omega \alpha i$ ) for another, Plato also echoes here Empedocles' claim that humans did not eat animal flesh during the reign of Love (B128) and his injunctions against eating meat in the current age (B136, B137).

19 Kahn, Plato and the Post-Socratic Dialogue, p. 223. Kahn suggests that both the Platonic and Empedoclean cycles of reincarnation must owe something to an older Orphic or Pythagorean tradition.

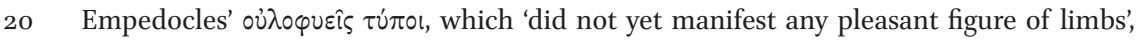
obviously differs from the Stranger's old, but fully formed, human beings. 
be more fully articulated in the Timaeus. ${ }^{21}$ Indeed, Empedocles' own sphairos and holy phrēn may be a relevant source of inspiration for such animistic ways of thinking about the cosmos. ${ }^{22}$ Another structural parallel can be found in the dynamic of presence and absence at work in each author's alternating cycles. In the Statesman, the cosmos enters the Age of Zeus as soon as the demiurge takes his hand off the rudder and 'withdrew to his lookout point' (272e); in Empedocles, the transition to the state of complete conglomeration takes place as Strife is slowly 'withdrawing to the extremity [of the cosmos]' (B36). ${ }^{23}$ In both cosmologies, the fundamental characteristics of the cosmos in each era are determined by this dynamic.

Finally, and most importantly for my argument, the Stranger cites Empedocles most directly by forcefully distinguishing his cosmology from Empedocles'. In an extended explanation of the reasons why the cosmos must participate in cycles of forwards and backwards motion, the Stranger definitively rejects the possibility 'that some pair of opposite-minded gods turn it' (270a). Unlike the rational-theological arguments employed in dialogues like the Euthyphro or Republic, what is being rejected here is not the Homeric anthropomorphism which attributes human emotion and war-like conflict to the gods. Instead, what is being rejected is specifically the possibility of two gods guiding (or ruling) the cosmos in turn in a way that would allow for a divergence in thinking between them. The cosmos can only be ruled by the unified, single-minded sovereignty of epistēme $\bar{e}$. If the cosmos does rotate in opposite directions at different times, Plato seems to say, it must be because an intelligent ruler is at one time present, at another time absent; it could not be because the cosmos admits of differing opinions on the way it should be ruled.

On the one hand, then, we have here a picture of the Statesman myth as indebted to Empedocles not just in the structural idea of cosmic cycles, but also in the particular characteristics of the cosmos in each age and in the minor details and flourishes that the Stranger adds to flesh out his account. But on the other hand, we hear the Stranger specifically differentiate his own

21 Kahn, Plato and the Post-Socratic Dialogue, p. 223.

22 Compare the cosmos as an animal with $\varphi$ póvnoıs at Statesman 269d with Empedocles'

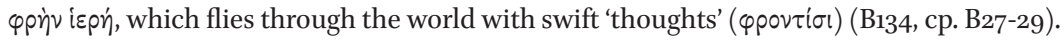
For a discussion of the relationship of the sphairos and holy phreen in these fragments, cf. Wright, Empedocles, p. 254.

23 Both authors use similar language to describe the withdrawal of their respective deities: compare the various forms of " $\sigma \tau \eta \mu l$ with its different prepositional prefixes in Plato's $\varepsilon i \varsigma$

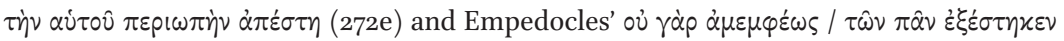

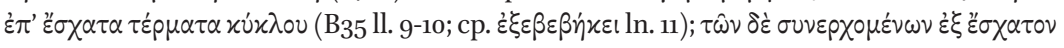

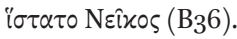


cosmology from Empedocles' by rejecting the possibility of two 'oppositeminded' gods ruling the cosmos in turn. Why does Plato go to such trouble to cite Empedocles in this complex way? I suggest that the Stranger's myth aims to persuade us of the fundamental impropriety of rule-by-many, i.e., of democratic rule. If (as nearly every Greek theorist would agree) there must be a certain symmetry between the structure of the cosmos and the type of rulership appropriate in the human political sphere, and if the cosmos is structured in such a way that specifically precludes the possibility of cosmic rule-by-many, then the type of rule called for by our own political situation must necessarily be non-democratic. In Section 3 of this paper, I argue that the Stranger demarcates the contours of the statesman's true rule of the city precisely through a critique of democratic rule, which has been prepared for his audience by means of the mythic critique of Empedocles' cosmic democracy. Before turning to this critique, however, I need to justify the characterization of Empedocles' cosmos as democratically structured.

\section{Empedocles' Cosmic Democracy}

Before turning to his texts, it is worth noting that Empedocles' personal commitment to democracy forms a distinct and often reiterated theme in the testamonia. ${ }^{24}$ While the biographies of philosophers by later Hellenic sources are not reliable, these reports give us a valuable glimpse of how a thinker like Empedocles was viewed in late antiquity and how his works were interpreted. Because I wish to suggest in Section 3 that Plato read Empedocles' cosmology as having a distinctively democratic bent, it is worthwhile to examine this

24 For a careful treatment of these testamonia, cf. P. S. Horky, 'Empedocles Democraticus: Hellenistic Biography at the Intersection of Philosophy and Politics', in M. Bonazzi and S. Schorn (eds.), Bios Philosophos: Philosophy in Ancient Greek Biography (Turnhout: Brepols Publishers, 2016), pp. 37-70. More general assessments regarding Empedocles' political involvements can be found in J. Burnet, Early Greek Philosophy, 4th edn. (London: A. \& C. Black, 1930), pp. 198-9; W. K. C. Guthrie, A History of Greek Philosophy, vol. 2 (Cambridge, U.K.: Cambridge University Press, 1965), pp. 130-1; Inwood, The Poem of Empedocles, pp. 6-8; G. S. Kirk and J. E. Raven, The Presocratic Philosophers: A Critical History with a Selection of Texts (Cambridge, U.K.: Cambridge University Press, 1957), pp. 281-2; G. Naddaf, The Greek Concept of Nature (Albany, NY: State University of New York Press, 2005), p. 140; Wright, Empedocles, pp. 6-9. Horky reserves any final judgement about the veracity of the stories. As for the rest of the scholars cited here, Burnet, Inwood, and Wright treat the stories with a healthy dose of skepticism, but none find reason to doubt the basic claim that Empedocles was a democrat and involved in democratic politics in Acragas in some substantial way. 
emphasis in the testamonia. Prior to Empedocles' lifetime, his native Acragas and the surrounding poleis in Sicily were ruled by tyrants, including the infamous 6th century tyrant Phalaris of Acragas, who purportedly burned his opponents alive in a bronze bull. ${ }^{25}$ A young Empedocles (who lived roughly 492-432 BCE) would have witnessed the height of Acragas' wealth and power in Sicily during the reign of the tyrant Theron (who ruled from 488-472 BCE) as well as its precipitous decline into political turmoil upon the rule being passed to Theron's son Thrasydaeus. ${ }^{26}$ Diodorus Siculus reports that Empedocles's father was involved in Thrasydaeus' overthrow and in the subsequent establishment of a democracy. ${ }^{27}$ Upon his father's death and the stirrings of a new tyranny, Empedocles is reported to have 'persuaded the Agrigentines to put an end to their factions and cultivate equality in politics'. ${ }^{28}$ We have a number of other (potentially overlapping) stories concerning Empedocles' commitment to democracy. One such story relates that, during a time of political unrest, Empedocles actively persecuted other politicians who planned to become tyrants and subvert the democracy. ${ }^{29}$ Another relates how Empedocles used his considerable wealth to break up an anti-democratic organization known as 'The Thousand', presumably an oligarchic conspiracy. ${ }^{30}$ It is even reported that the Agrigentines had offered Empedocles to become their king, which offer Empedocles turned down ostensibly because he was a democrat and disagreed with monarchy as a form of rule. ${ }^{31}$ Empedocles' democratic activities would have made him enemies amongst the Agrigentine elite, however, and one of the more plausible stories of the philosopher's death relates that he perished in exile after the aristocrats of Acragas plotted against him. ${ }^{32}$ Regardless of whether such stories are factually accurate, these testamonia show that later

\footnotetext{
25 Naddaf, The Greek Concept of Nature, p. 140.

26 Guthrie, A History of Greek Philosophy, pp. 130-1.

27 Diodorus Siculus (11.23); cf. Guthrie, A History of Greek Philosophy, pp. 130-1.

28 Diogenes Laertius (8.72). All translations and references to Diogenes Laertius are from the Loeb edition: R. D. Hicks, Diogenes Laertius: Lives of Eminent Philosophers vol. II, Books 6-10 (Cambridge, MA: Harvard University Press, 1925). Diogenes Laertius (8.57), Sextus (Against the Professors 7.6), and Quintilian (3.1.8) report that Aristotle claimed Empedocles invented rhetoric, and that Gorgias of Leontini was his student. Naddaf and Wright both speculate on a connection between Empedocles' democratic activities and his oratorical accomplishments (Naddaf, The Greek Concept of Nature, p. 140; Wright, Empedocles, pp. 8-9).

29 Cf. Diogenes Laertius (8.64) for the strange story of Empedocles at dinner with the aspiring tyrants.

30 Diogenes Laertius (8.64); cf. Wright, Empedocles, p. 8.

31 Diogenes Laertius (8.63-4).

32 Diogenes Laertius (8.67); cf. Guthrie, A History of Greek Philosophy, p. 131.
} 
Greeks understood Empedocles' life and works in a democratic light, and that Plato could reasonably have seen him in that light as well. ${ }^{33}$ Indeed, there is evidence that interpreters as early as Aristotle regarded Empedocles as a defender of democracy. ${ }^{34}$

More importantly, though, we find a democratic sympathy reflected in the very structure of Empedocles' cosmos. We have already observed how Empedocles describes his cosmic cycles with the language of 'ruling in turn'. In using this language, he draws directly upon the legal terminology of democracy, where the sharing and rotation of offices and magistracies form an essential aspect of democratic governance that differentiates it from oligarchic or monarchic forms of rule. In Euripides' Suppliants, for example, Theseus challenges the Theban herald when he asks after 'the master of the land' ( $\gamma \hat{\eta} \varsigma$

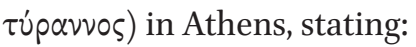

To begin with, stranger, you started your speech on a false note by asking for the master here. The city is not ruled by a single man but is free

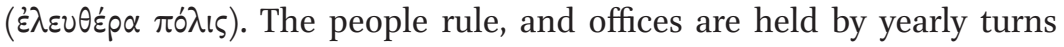

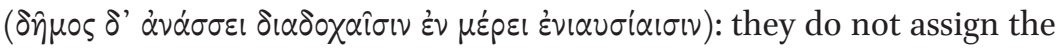
highest honors to the rich, but the poor also have an equal share.

EURIPIDES, SUPPLIANTS 403-408 35

For Euripides' Theseus, it is the sharing of offices 'in turn' ( $\dot{\varepsilon} \nu \mu \dot{\varepsilon} \rho \varepsilon l$ ) amongst all the dèmos that separates democratic Athens from tyrannical Thebes, making

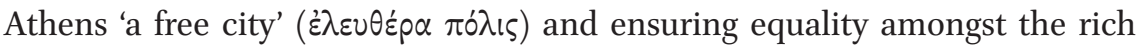
and poor alike. A passage from Xenophon's Hellenica likewise illustrates how the practice of 'ruling in turn' was considered an expression of the democratic value of equality. Cephisodotus, appealing to the Athenian audience's democratic sentiments, challenges the Spartan ambassador's proposal regarding the division of military and naval control amongst the allies:

'Answer me', he said, 'Timocrates of Lacedaemon, did you not say a moment ago that you had come with intent to make the alliance on

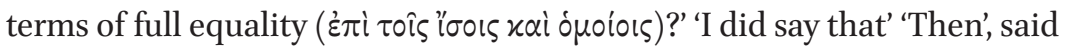

33 Note, however, that an exhaustive comparison of the portrayal of Empedocles in these testamonia and in Plato's works would require determining whether and to what extent Plato's conception of democracy might differ from that of the much later Diogenes. I thank Carol Atack for this observation.

34 Diogenes Laertius (8.64); cf. Horky, 'Empedocles Democraticus', pp. 37-48.

35 Loeb translation: D. Kovacs, Euripides: Suppliant women; Electra; Heracles (Cambridge, MA: Harvard University Press, 1998). 
Cephisodotus, 'is there anything more equal than that each party in turn should be leader of the fleet, and each in turn leader of the army ( $\dot{\varepsilon} \nu \mu \varepsilon \rho \varepsilon \varepsilon$

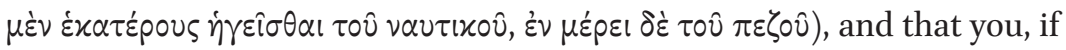
there is any advantage in the leadership by sea, should share therein, and we likewise in the matter of leadership by land?' Upon hearing this the Athenians were led to change their minds, and they voted that each party should hold the leadership in turn for periods of five days.

HELLENICA VII.1.13-14

When Cephisodotus plays on the Athenian audience's recognition of 'equal-

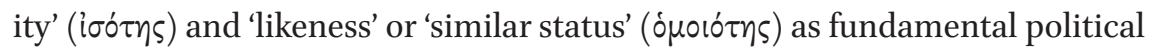
goods, he is able to convince them that the military leadership positions should be shared according to a strict rotation of rule, in keeping with democratic custom. ${ }^{37}$ In the Politics, Aristotle identifies the practice of 'ruling and being ruled in turn' as an essential feature of democracy, insofar as it is the condition of possibility for the particular kinds of freedom and equality aimed at by this form of rule:

A fundamental principle of the democratic constitution is freedom. (For this is what people are accustomed to say, on the ground that only in this constitution do they have a share of freedom - which is what they declare every democracy aims at.) One component of freedom is ruling and being

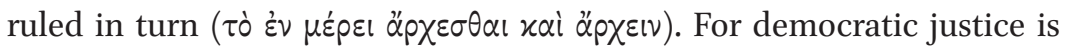
having an equal share on the basis of number, not worth ... Another is to live as one wishes. For this they say is the function of freedom, if indeed it is a feature of one who is enslaved not to live as he wishes. This, then, is the second mark of democracy; and from it has come the call not to be ruled, preferably not by anyone, or failing that, 〈to rule and be ruled $\rangle$ in turn. And in this way the second mark contributes to the freedom based on equality.

POLITICS VI.2, 1317A40-B17 38

36 Loeb translation: C. L. Brownson, Xenophon: Hellenica, vol. II, Books 5-7 (Cambridge, MA: Harvard University Press, 1921).

37 Cp. Aristotle, Politics III.6, 1279a9-10: 'When the constitution of city-states is based on

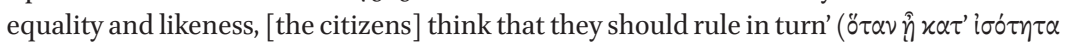

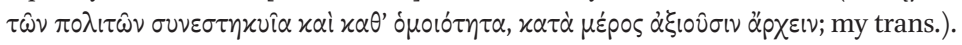

38 Clarendon translation: D. Keyt, Aristotle, Politics: Books V and VI (Oxford: Clarendon Press, 1999). Angled brackets in translation. 
The democrat, Aristotle suggests, is really a pragmatic anarchist. The kind of freedom the democrat prizes is the freedom of 'living as one likes', i.e., the freedom not to be beholden to the authority of anyone else. To be ruled by another is precisely to live not as one likes, and is tantamount to enslavement. Anarchy not being practicable (for reasons left unspecified), the next best option is for each citizen to rule and be ruled in turn, for in this way each will have an equal share of the rule over all others. Aristotle assumes that it is impossible for all to rule over all simultaneously; thus, they do so sequentially, i.e., 'in turn'. As he puts it elsewhere: 'For it is not possible for all to rule at the same time, but

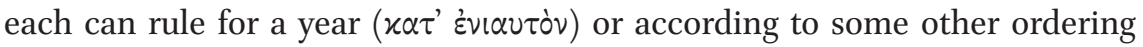
of time' (Politics II.2, 1261a32-34; my trans.). Presumably this maximizes the freedom the democrat wishes to achieve, for over time everyone will subject to everyone else; today I live as you like, but tomorrow you will live as I like. 'Democratic justice' is achieved by rotation of office because the share of the rule apportioned to each is not based on merit, wealth, or any other criteria besides the equal status every man has as free citizen of the polis. The sharing and rotation of offices thus follows directly from the 'fundamental principle' ( $(\dot{\pi} \dot{0} \theta \varepsilon \sigma \varsigma \zeta)$ of freedom at which democracy aims, and Aristotle concludes that this practice is an essential institution of democracy, referring to it as 'the rul-

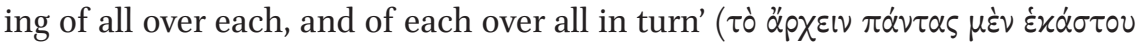

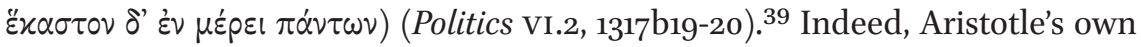
Constitution of Athens shows that the language of ruling 'in turn' formed a vital

39 For a fuller analysis of Politics vi.2, 1317a4o-b17 in context, cf. Keyt, Aristotle, Politics, pp. 195-200, which I draw from here. While Aristotle is critical of the ideals of democratic freedom and democratic justice as they are articulated in Politics vi.2 (cf. e.g. Politics V.1), elsewhere he is sympathetic to the practice of rotation of rule. Amongst people who are by nature similar to one another, it is harmful and unjust to have unequal distribution of the rule; 'therefore it is just [for each citizen] to rule no more than [he is] ruled,

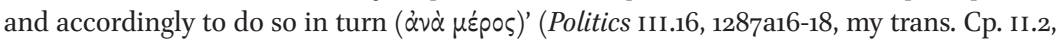
1261a29-b6). Because it is nearly impossible that human rulers should be equal in virtue to gods or divine heroes, it is necessary instead that 'all should share alike in ruling and

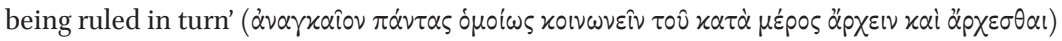
(Politics VII.14, 1332b26-27, my trans.). Nevertheless, on the very rare occasion one man is so preeminent in virtue that he surpasses all others, it is just that he should be supreme ruler over all: he should not 'be expected to take a turn in being governed' (ov' $\tau$ ' $\alpha \xi$ เov̂v

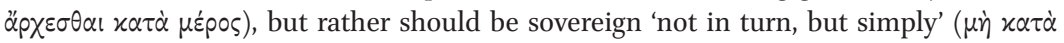

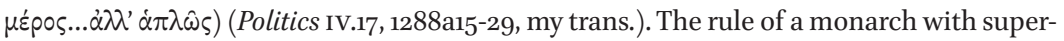
lative virtue is preferable in principle to polity: even in the 'best state' the sharing of rule must be abandoned if someone possessing godlike virtue appears (Politics III.13, 1284b2534). For Aristotle, rotation of rule is a practical necessity, not a per se political good. Cf. W. R. Newell, 'Superlative Virtue: The Problem of Monarchy in Aristotle's "Politics", The Western Political Quarterly, 40, no. 1 (Mar., 1987), pp. 159-178. 
aspect of 5 th-4th century Athenian legal terminology. There Aristotle explains

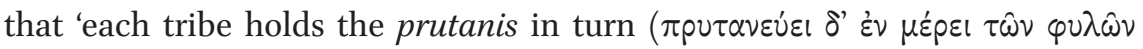

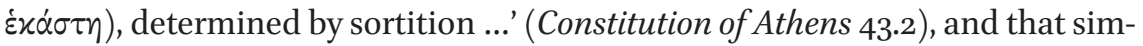
ilarly the Nine Archons (the six thesmothetai, the archon, the basileus, and the

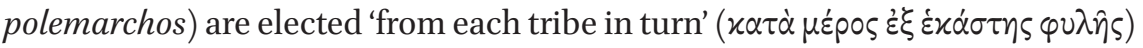
(Constitution of Athens 55.1-2; my trans.). Plato himself viciously criticizes this Athenian policy at Statesman 298e-299a, where he describes the offices of rul-

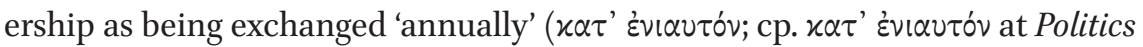

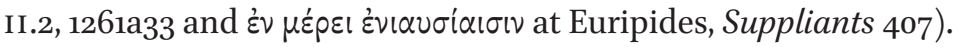

The democratic value of a cyclical exchange of power had other expressions in Athenian politics besides the rotation of offices and magistracies. Rotation of rule appears to be deeply connected to proto-democratic or isonomic juridical practice and the concomitant development of the concept of ise goria, which, like rotation of rule, is often evoked with the language of 'taking turns'. Such language is used in contexts where a speaker demands equal hearing for dissenting opinions: e.g., for the plaintiff and defendant in the courtroom and, later, for contrary proposals in the Assembly. ${ }^{40}$ The importance of equal hearing to early democratic justice is vividly dramatized in Aeschylus' Eumenides, where the testimonies of the gods are treated with equal weight as those of mortals, and the disputants in Orestes' case are consistently represented as demanding for themselves (and offering to one another) equal consideration for both sides of the case: i.e., to hear and be heard 'in turn' ( $\dot{\varepsilon}^{\nu} \mu \varepsilon$ ' $\left.\rho \varepsilon ı\right)$ (cf. Eumenides 198-200, 436-42, 585-7; cp. Libation Bearers 332). ${ }^{41}$ Euripides likewise portrays Athenian proto-democratic jurisprudence in terms of equal hearing:

Chorus Leader: Who can decide a plea or judge a speech until he has heard a clear statement from both sides? Iolaus: My lord, since this is the law in your land [i.e., Athens], I have the right to hear and be heard

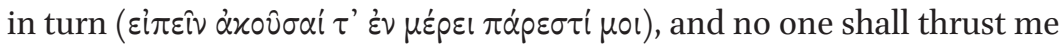
away before I am done, as they have elsewhere.

HERACLEIDAE $179-83^{42}$

40 Demosthenes links democratic freedom and isēgoria with the right to bring forward indictments in court (Against Meidias 124). For the development of isēgoria, cf. J. D. Lewis, 'Isegoria at Athens: When Did It Begin?', Historia: Zeitschrift für Alte Geschichte, Bd. 20, H. 2/3 (2nd Qtr., 1971), pp. 129-40.

41 Aristophanes later parodies the idea of mortals and gods giving heed to one another (and thus ruling one another) 'in turn' at Birds 1224-29.

42 Loeb translation: D. Kovacs, Euripides: Children of Heracles; Hippolytus; Andromache; Hecuba. (Cambridge, MA: Harvard University Press, 1995). Cp. Heracleidae 179-83 with 
Unlike in tyrannical Mycenae, the refugee Iolaus enjoys a position of authority in Athenian court, where the law demands that the Herald, the Chorus Leader, and even King Demophon must content themselves to listen in their turn as he gives his defense. Invocations of this right appear in 4th century Athenian courtroom rhetoric as well: e.g., Demosthenes opens his Against Phormio by imploring the jurymen to 'hear us with goodwill as we speak in our turn'

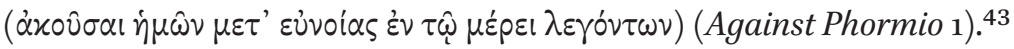

But the Chorus Leader of the Heracleidae also hints at a broader democratic importance for equal hearing. Not only is it impossible to judge suits or pleas

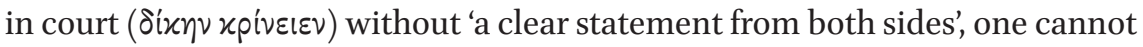
form a judgement about any kind of speech in general (rvoin $\left.\lambda o^{\prime} \gamma o v\right)$ without it. The essential role of speaking in turn for debate in the Assembly is thematized in the later oratorical tradition. Both Demosthenes and Aeschines, for example, connect proper democratic governance with equal hearing and taking turns. In Demosthenes' Second Olynthiac, the speaker concludes by exhorting the Assembly to abandon the factionalism promoted by the symmoriai and ensure a proper democratic distribution of power amongst the branches of Athenian government (Second Olynthiac 29-31). He implores the audience to 'become yourselves again' and 'make common deliberation, speaking, and acting' ( $i \mu \omega \hat{\nu}$

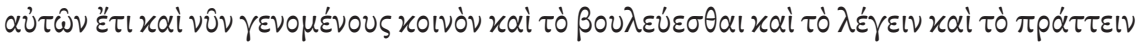
$\pi \circ(\hat{\eta} \sigma \alpha)$, stressing that equitability demands both that all should take part in the campaign 'in turn' ( $\varkappa \alpha \tau \dot{\alpha} \mu$ źpos) and that all those present in the Assembly should be given equal opportunity to speak so that the best advice may be followed (Second Olynthiac 30-31; my trans.). Aeschines similarly emphasizes the vital importance of isēgoria in Against Ctesiphon, beseeching the loud and tumultuous Assembly to recall that an orderly exchange of the platform for speaking (to bèma) amongst all the citizens is prescribed by the laws, a practice which he attributes (perhaps anachronistically) to the inception of Athenian democracy in Solon's reforms (Against Ctesiphon 2). It is only when each citizen, in order of age, can 'declare his opinion on each topic in his turn' ( $\dot{\varepsilon} \nu \mu \varepsilon$ é

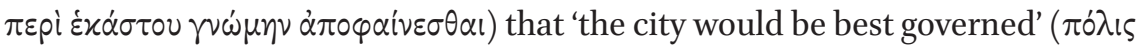

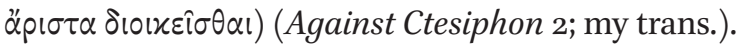

Returning to Euripides' Suppliants, we can now understand why Theseus is able to move easily from aligning democratic justice, equality, and freedom

Hecuba 1129-31. As in the Suppliants, Euripides in the Heracleidae casts Heroic-era Athens as a proto-democracy: cf. 1l. 34-37, 415-24.

43 Loeb translation: A. T. Murray, Demosthenes: Orations, vol. IV (Cambridge, MA: Harvard

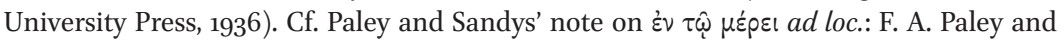
J. E. Sandys, Select Private Orations of Demosthenes with Introductions and English Notes, vol. I (Cambridge, UK: Cambridge University Press, 1874). 
with rotation of office in the passage above (Suppliants 403-8) to aligning these same values with the concept of isēgoria just afterwards (ll. 429-41), where he sums up thus: 'Freedom consists in this: "Who has a good proposal and wants to set it before the city?"... What is more equal for a city than this?' (1l. 438-41). ${ }^{44}$ The same dynamic of cyclically exchanging authoritative and subordinate roles amongst equals is expressed both in rotation of office and in the equal hearing of differing opinions in the Assembly. Gathering the threads of these various texts together, we see how an equal distribution of power throughout the citizenry means not only that offices of rulership are rotated, but also that each disputant in their turn may make their case to the jury, and that each citizen in their turn may command the attention of the Assembly, for in this way all voices can have equal hearing in the shaping of democratic jurisprudence and policy-making. A cyclical exchange of power was thus considered intrinsic to the executive, judicial, and legislative functions of democratic governance. In a wide variety of texts from the $5^{\text {th }}$ and 4 th century, we see this exchange signaled by variations on the phrase 'in turn'.

When Empedocles refers to Love and Strife as 'ruling in turn', then, he is drawing on a specific Greek political tradition, using the conceptual vocabulary of that tradition to describe the structure of the cosmos. The cosmos is organized like a democracy, for the fundamental forces at work there alternate cyclically between periods in which one reigns supreme and the other is subordinated and vice versa, just as the citizens in a democratic polis trade off ruling and being ruled in turn. At one time, as it were, the cosmos lives as Love likes, while at another, it lives as Strife likes.

Indeed, Jaeger has even gone so far to suggest that Empedocles meant to include the basic material components of the cosmos as citizens in his cosmic democracy. Jaeger sees a tendency in interpretations of Empedocles' cosmology to assume a kind of hierarchy between the divinities of Love and Strife and the elements, the former being the sole ruling principles, while the later are subordinate to their authority. According to Jaeger, this tendency (begun by Aristotle) fundamentally misunderstands the relationship between the constituents of Empedocles' cosmos. ${ }^{45}$ Jaeger argues that Love, Strife, and the four elements were conceived by Empedocles to be 'gods of equal rank'. He interprets Empedocles' cosmology as specifically geared towards attacking Hesiodic cosmologies that establish a hierarchy of sovereignty based on the relative primordiality of gods, where the oldest ( $\pi \rho \varepsilon \sigma \beta u ́ \tau \alpha \tau o \varsigma)$ gods are the most honored

44 I have altered the Loeb translation slightly.

45 W. Jaeger, The Theology of the Early Greek Philosophers: The Gifford Lectures 1936 (London: Oxford University Press, 1968), p. 140. 
$\left(\tau \mu \mu \omega^{\prime} \tau \alpha \tau \circ \varsigma\right) .{ }^{46}$ In Empedocles' cosmology, by contrast, '[n]one of these gods is more primordial than the others: they are all equal, but each has its own ethos, and in the cycle of time each prevails in its turn, in the bodies and lives of individual plants, animals, and men, no less than in the life of the cosmos itself' ${ }^{7}$ In other words, 'the aristocratic order of the older theogonic thought which was all based on difference of rank, age, and genealogy, is superseded [sic] now by the democratic equality of all the elementary and moving forces which make up Empedocles' cosmos', a view which Jaeger claims is inextricably linked to Empedocles' own political commitments. ${ }^{48}$

Placed as it is in a synoptic treatment of early Greek theology, Jaeger's analysis of Empedocles' cosmology perhaps leaves a little to be desired in terms of detailed attention to the texts. The basic thesis of Jaeger's argument, however, is firmly supported by a contemporaneous article by Gregory Vlastos. In his masterful study 'Equality and Justice in Early Greek Cosmologies', Vlastos argues that early Greek thinkers in the poetic, philosophic, and medical traditions conceived of the cosmos as structured by 'cosmic justice': 'a conception of nature at large as a harmonious association, whose members observe, or are compelled to observe, the law of the measure.49 Vlastos here sets out to show that this state of cosmic harmony and justice was understood by these

46 Jaeger, Theology, p. 139.

47 Jaeger, Theology, p. 138, my emphasis. Jaeger bases his interpretation on a careful examination of $\mathrm{B}_{17}$, especially $\ln .27$ and its context, where he argues $\tau \alpha \hat{\tau} \tau \alpha . . . \pi \dot{\alpha} \nu \tau \alpha$ must be understood as referring to both Love and Strife and the four elements (Jaeger, Theology, pp. 139-140 and his fnn. 42, 48). Graham seems to agree with this conclusion and cites Vlastos' paper in support of the idea that the cosmos pictured by Empedocles is thus to be understood as invoking the 'institutions of participatory democracy, which have magistrates taking turns in office, to illustrate their equality' (Graham, Early Greek Philosophy, p. 425). Wright, on the other hand, argues that $\tau \alpha \hat{\tau} \tau \alpha . . . \pi \dot{\alpha} \nu \tau \alpha$ must refer to the elements alone (Wright, Empedocles, pp. 170-1), and Vlastos himself seems to assume as a matter of course that ln. 27 discusses only the elements (G. Vlastos, 'Equality and Justice', p. 159 and fn. 29). It does not seem to me that this particular line can be definitively read either way. However, a thorough appreciation of Empedocles' commitment to cosmic democracy in some other fragments certainly complicates any simplistic view of Love and Strife as sovereign rulers over the elements, and lends credence to Jaeger's interpretation.

48 Jaeger, Theology, p. 140. For the purposes of my argument, it is inconsequential whether Jaeger is ultimately correct about the equiprimordiality of and equality between Love, Strife, and the elements. Nor is it necessary for my argument to describe in overly precise terms the cosmic-political relationship between Love and Strife and the elements (indeed, it seems doubtful even whether Empedocles did so in his texts). All that is necessary for my point here is that we recognize that Empedocles describes both the relationship between Love and Strife and the relationship amongst the elements in the essentially democratic terms of 'ruling in turn'. 
thinkers primarily in terms of equality: 'Cosmic equality was conceived as the guaranty [sic] of cosmic justice: the order of nature is maintained because it is an order of equals'.$^{50}$ Empedocles provides for Vlastos an entry point for considering this way of thinking in the philosophic tradition. Vlastos emphasizes here several aspects of Empedocles' cosmos already mentioned, including the equality of the elements (B17 ll. 27, 35) and the fact that both Love and Strife and the elements are thought of as 'ruling in turn'.51 Similarly to Jaeger, Vlastos observes that the thoroughgoing equality amongst the constituent aspects of the cosmos implies that 'the universe cannot be a 'monarchy', for no power within it possesses the qualifying primogeniture'; instead, the cosmos 'must be an isonomia, for it conforms to the democratic principle of rotation of office. ${ }^{52}$ Vlastos supports these conclusions with a close reading of fragment B30, where he finds cosmic justice being described in essentially democratic terms. ${ }^{53}$ While I agree with Vlastos' reading of the fragment, I would like to probe a little deeper here and show just how much Empedocles relies on the conceptual vocabulary of democracy in B30 and the related B 115 for his analysis of the political structure of the cosmos.

B3o reads as follows:

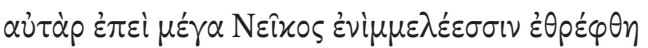

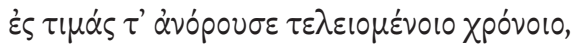

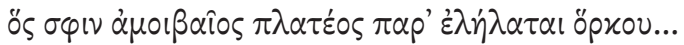

But when great Strife was nourished in its limbs,

It leapt up to its office as the time for exchange was being fulfilled

Which had been marked out for them [i.e., Love and Strife] by a broad oath ... (my trans.)

This fragment should be compared with the first two lines of B115, which concerns the exile of a criminal daimōn:

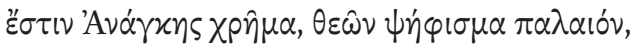

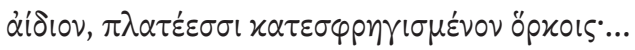

50 Vlastos, 'Equality and Justice', p. 156. Emphasis in original.

$5^{1}$ Vlastos, 'Equality and Justice', p. 159.

52 Vlastos, 'Equality and Justice', p. 160.

53 Vlastos, 'Equality and Justice', p. 160-1. 
There is an oracle of necessity, an ancient decree of the gods,

Eternal, sealed up with broad oaths ... (my trans.)

These lines establish the authority of a cosmic justice that requires the punishments for the murdering daimōn, namely, the exile and the cycle of reincarnations that are described in the remaining lines of the fragment.

We should dwell here on the vivid political images Empedocles deploys to describe the structure of the cosmos. In B3o, Strife leaps up ${ }^{54}$ to its 'prerogative', 'established right', or 'office' ( $\left.\tau \mu \eta)^{\prime}\right)$. The image is of an orderly legal transaction at an established time for exchange of power. ${ }^{55}$ Strife does not seize power in an illegal coup, but rather takes over what is its $\alpha \hat{\imath} \sigma \alpha$, its due share of the rule. ${ }^{56}$ This legal exchange of power is ratified by a 'broad oath. ${ }^{57}$ Vlastos notes that the 'broad oaths' of B115 'represent the binding, inviolate, necessary character of that decree [i.e., the $\theta \varepsilon \hat{\omega} \nu \psi \eta \dot{\eta} \varphi(\sigma \mu \alpha]$, which is an 'oracle of Anankē'.58 Connecting this with the close relationship of Anankē and Dikē in Parmenides' poem, Vlastos interprets these 'broad oaths' in B3o and B115 as 'allud[ing] to the orderliness of existence conceived under the aspect of justice. 59 The primary function of the image of 'broad oaths' is thus to indicate

54 Both Garani and Wright hear violent undertones to the verb ávópovøe (M. Garani, 'Cosmological Oaths in Empedocles and Lucretius', in A. H. Sommerstein and J. Fletcher (eds.), Horkos: The Oath in Greek Society (Exeter: Bristol Phoenix Press, 2007), pp. 189-202, 264-67, p. 194 fn. 26; Wright, Empedocles, p. 191). None of the citations listed in the LSJ for the verb avopovi have necessarily violent contexts, though, and Garani herself interprets the fragment to mean that Love and Strife 'agree voluntarily as equals to undertake the duty of ruling successively within the world' (Garani, 'Cosmological Oaths', p. 191).

55 Garani, 'Cosmological Oaths', p. 191; Vlastos, 'Equality and Justice', p. 161.

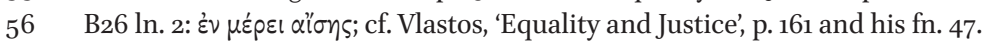

57 Wright suggests that it is not particularly important to identify who is swearing the oath (Wright, Empedocles, p. 191), but it seems to make the most sense to assume it is 'sworn' by Love and Strife.

$5^{8} \quad$ Vlastos, 'Equality and Justice', p. 160; emphasis in original.

59 Vlastos, 'Equality and Justice', p. 160-1 and his fn. 43. Garani rightly corrects the tradition of interpretation, beginning with Simplicius, that simply equates these two usages of op pxos with $\dot{\alpha} \nu \alpha \gamma \gamma x \eta$. This tradition ignores the important difference between the first instance (guaranteeing the mutual succession of Love and Strife) which is inviolable, and the second instance which deals precisely with a öpxos that is transgressed by a daimōn (Garani, 'Cosmological Oaths', p. 193). Nevertheless, Garani acknowledges that the repetition of the 'broad oath' points to an important connection between the cosmic and daemonic cycle. More importantly for our purposes, she concludes that even if the cycle of the mutual succession of Love and Strife are not to be thought of as determined by $\alpha \dot{\alpha} \alpha \gamma \gamma \eta$, the function of the 'metaphor' of the öpxos in B3o is 'to maintain within [Empedocles'] system the dualism between Love and Strife and the equal status that he tries to accord with them and to block any impression that both might be jointly subject to a higher authority' (Garani, 'Cosmological Oaths', p 194). 
the 'equalitarian justice of rotation of office' that forms the fundamental structure of the cosmos. ${ }^{60}$

Beyond the repetition of the 'broad oath' from B30, the first two lines of B115 are rife with the conceptual vocabulary of democracy as well. In regard to

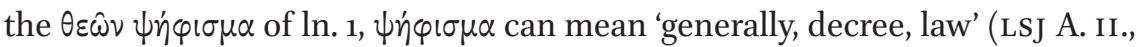
where B115 ln. 1 is listed as one instance of this general meaning). The more common meaning, however, is a 'proposal passed by a majority of votes: esp. measure passed by a popular assembly, decree, act' (LSJ A.). Thus Empedocles represents his divinities here as 'voting to accept and swearing to abide by what must inevitably happen'.61 The participle $x \alpha \tau \varepsilon \sigma \varphi \rho \eta \gamma\left(\sigma \mu \varepsilon \dot{\varepsilon}{ }^{6}\right.$ v in B115 ln. 2 is from $x \alpha \tau \alpha \sigma \varphi p \alpha \gamma i \zeta \omega$ ('to seal up' or 'secure'), an interesting verb that is not well-attested prior to the end of the $5^{\text {th }}$ century вСЕ. The few texts from this period in which it appears, however, illustrate that the verb has powerful connotations in the context of Greek democracy. In Isocrates' Trapeziticus, for instance, the accuser indicts the banker Pasion's friend Pythodorus for tampering with the voting-urns ( $\left.\tau \dot{\alpha} \varsigma \dot{\delta} \delta \delta^{\prime} \alpha \varsigma\right)$ containing the names of those nominated to judge the dramatic contests at the Dionysian festival. The accuser claims that

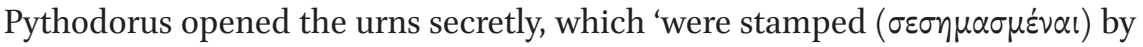
the Prytanes and sealed up ( $\varkappa \alpha \tau \varepsilon \sigma \varphi p \alpha \gamma\left(\sigma \mu \varepsilon^{\prime} v \alpha l\right)$ by the Choregi ...' (Trapeziticus 17.34 1l. 3-4; my trans.) and guarded by the treasurers on the Acropolis. The act of stamping ( $\sigma \eta \mu \alpha i v o \mu \alpha l)$ and sealing up ( $\varkappa \alpha \tau \alpha \sigma \varphi p \alpha \gamma i \zeta \omega)$ the voting urns serves to ratify the impartiality of the democratic selection of judges for the contests; hence tampering with the seals of the urns threatens the legitimacy of the democratic process itself. Apparently the process of stamping and sealing up went hand-in-hand as a common form of ratification, so much so that the author of the Suda sees them as nearly equivalent. Cf. Suda s.v. $\Sigma v \sigma \sigma \eta \mu \alpha i v \varepsilon \sigma \theta \alpha$ :

That which they call 'to seal up' ( $\kappa \alpha \tau \alpha \sigma \varphi p \alpha \gamma$ i $\sigma \alpha \sigma \theta \alpha l)$, this the orators

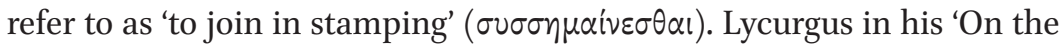
Priestess': 'So that is has been ordered by majority vote ( $\dot{\pi} \pi \dot{i} \psi \eta \varphi$ i $\sigma \mu \alpha \tau \circ \varsigma)$ that the priestess must join in stamping ( $\sigma 0 \sigma \sigma \eta \mu \alpha i v \varepsilon \sigma \theta \alpha l)$ the documents'. (My trans.)

SUDA 1675

In the Lycurgus fragment attested in this entry, the process of stamping official documents is ordered by the $\psi \dot{\eta} \varphi \mid \sigma \mu \alpha$, the majority vote. When the priestess joins in stamping the documents, she ratifies this majority vote and gives her assent to the decision of the democratic process. The fragment thus illustrates

\footnotetext{
$60 \quad$ Vlastos, 'Equality and Justice', p. 161.

61 Wright, Empedocles, p. 272; cp. Garani, 'Cosmological Oaths', p. 192.
} 
the reciprocal power relations that form the basis for democratic governance: on the one hand, the priestess is required by the majority vote to stamp the documents, on the other, that vote itself is only authorized and made officially valid once the priestess has joined in stamping the official documents.

A fruitful comparison can be made between the function of this semantic complex in Empedocles' fragments and in Aeschylus' Suppliants. ${ }^{62}$ The concept of the $\psi \dot{\eta} \varphi \mid \sigma \mu \alpha$ (and the closely related $\psi \hat{\eta} \varphi \circ \varsigma$ ) play an integral role in the action of the play, where King Pelasgus cannot immediately grant the Chorus of the Danaides admittance to Argos without first putting the question to a vote amongst the people at large. ${ }^{63}$ From the moment the Chorus receives the news of the $\psi \eta \varphi i \sigma \mu \alpha \tau \alpha$ from their father Danaus (cf. 1l. 6oo-1; also referred to

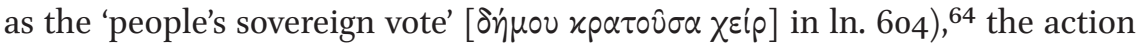

62 C. J. Herington has argued that Aeschylus visited Sicily during Empedocles' lifetime, and that his plays were performed there (C. J. Herington, 'Aeschylus in Sicily', The Journal of Hellenic Studies, 87 (1967), pp. 74-85). Herington elsewhere collects much evidence for the mutual influence of the poet and the philosopher on one another (C. J. Herington, 'A Study in the 'Prometheia', Part I: The Elements in the Trilogy', Phoenix 17.3 (1963), pp. 180197, pp. 192-7), even going so far as to suggest that fragment 44 of Aeschylus' Danaides (the third part of the Suppliants' tetralogy) may be a near quote from some lost part of Empedocles' poems (Herington, 'A Study in the 'Prometheia', 'p. 195 fn. 55; cf. Herington, 'Aeschylus', p. 81). Herington likens fragment 44 to Empedocles B71-73. The Aeschylus fragment is certainly remarkably similar to Empedocles' poem in its representation of Aphrodite as more a cosmic attractive and procreative force than as an anthropomorphized, personified deity, and we should compare the very similar hymn to Venus in Lucretius' De Rerum Natura Book I, ll. 1-43 (a passage that is widely accepted as demonstrating the influence of Empedocles' cosmology on Lucretius). While Herington's argument for mutual intellectual influence between Empedocles and Aeschylus focuses mainly on similarities he finds in Aeschylus' Prometheus Bound, the common democratic language employed in B115 and Aeschylus' Suppliants may support Herington's findings from a different vantage.

63 Suppliants 365-401 showcase the dramatic political tension between rule-of-one and ruleof-many at the heart of the play. After Pelasgus' claim that he 'cannot make a binding

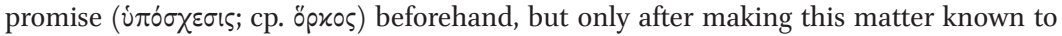
the whole citizen body', the Chorus replies: 'You are the city, I tell you, you are the people! A head of state, not subject to judgement, you control the altar, the hearth of the city, by

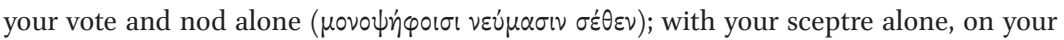
throne, you determine every matter' (emphasis in translation). Pelasgus shows a singleminded commitment to the priority of democratic rule over his own sovereignty: 'I have already said I am not prepared to do this without the people's approval, even though I have the power ...' (cf. ll. 397-401). All translations and line number references from Aeschylus' Suppliants are from the Loeb edition: A. H. Sommerstein, Aeschylus vol. I: Persians, Seven Against Thebes, Suppliants, Prometheus Bound (Cambridge, MA: Harvard University Press, 2008).

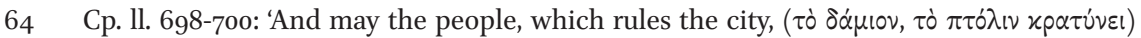
protect well the citizens' privileges, a government acting with craft and foresight for the common good ...' 
of the play accelerates quickly towards its climax, when Pelasgus informs the herald of the Egyptian cousins that the people of Argos have approved the Chorus' supplication:

That is the unanimous vote ( $\psi \eta \hat{\eta} \varphi \circ$; cp. 1l. 640, 644, 963-5) that has been passed and enacted by the people ( $\delta \eta \mu o ́ \pi p \alpha x \tau \circ \varsigma)$ of the city, never to surrender this band of women by force. This decision has been nailed down with a nail that has pierced right through, so that it stays fixed. These words are not written on tablets, nor sealed up ( $\propto$ $\tau \varepsilon \sigma \varphi p \alpha \gamma(\sigma \mu \varepsilon \dot{v} \alpha)$ in a folded sheet of papyrus: you hear them plainly from the lips and tongue of a free man.

AESCHYLUS, SUPPLIANTS 943-949

Here again the verb $x \alpha \tau \alpha \sigma \varphi p \alpha \gamma i \zeta \omega$ appears in the context of the democratic decision-making process. Ordinarily, Pelasgus implies, the $\psi \hat{\eta} \varphi \circ \varsigma$ would be 'sealed up' in written law, ratifying the people's decision and codifying it permanently (just as how the priestess must 'join in stamping' the official documents in the Lycurgus fragment). In the context of the action of the play, however, the democratic decision of the people need not be immediately sealed up in written law precisely because there is a king who puts the force of his rule behind it. In the Empedocles fragment, by contrast, the $\psi \dot{\eta} \varphi i \sigma \mu \alpha$ of the gods must be sealed up with broad oaths precisely because there is no such cosmic king who could enforce the decree solely with the power of his living voice.

We can thus see how the conceptual vocabulary that Empedocles mobilizes to describe the structure of the cosmos has a thoroughly democratic context. From the power dynamic between Love and Strife in $\mathrm{B}_{17}$ and B30, to the cosmic justice described in B115, to the way in which the elements also 'rule in turn' in B26, we see Empedocles again and again portraying the cosmos to be essentially structured as a democracy, where shared rule between constituents and the cosmic justice this implies are eternally assured through mutually sworn oaths and ratified by divine 'vote'. These political aspects of Empedocles' cosmos manifest as part of a broader Greek intellectual tradition, the central feature of which is (as Jaeger puts it) 'the interpretation of natural processes by means of analogies taken from man's political and social life. ${ }^{65}$ Part and parcel of this tradition, though, was an appreciation of the normative implications that such interpretations carried. Jaeger again explains: 'the relationship of the social element in Greek thought to the cosmological was always a reciprocal one: as the universe was understood in terms of political ideas such as diké,

65 Jaeger, Theology, p. 139 . 
nomos, moira, kosmos, equality, so the political structure was derived throughout from the eternal order of the cosmos'.66 Did Empedocles see his own cosmology as having direct implications for human politics? We cannot be certain that he did on the basis of the extant fragments alone, although the testamonia make it clear that later Greek authors certainly interpreted his work in that way. Plato, immersed as he was in the democratic milieu of $5^{\text {th- }}$ th century Athens, would have immediately recognized the democratic resonance of phrases like en merei kratein and the corollary concept of 'taking turns'; indeed, he criticizes this Athenian practice in the Statesman. The very fact that Plato consistently alludes to various aspects of Empedocles' cosmology in a context where he himself is explicitly concerned with the relation between cosmic structure and human politics suggests that Plato understands Empedocles' cosmology as also having definite political implications. This insight is key to understanding the myth of the Statesman and its function in the argument of the dialogue. There the myth of the two ages serves as a foil to Empedocles' cosmic democracy and the Stranger appears as an anti-democratic champion of both human and cosmic epistemic monarchy.

\section{3 \\ Plato's Rejection of Cosmic and Human Democracies in the Statesman}

In S. S. Monoson's monograph entitled Plato's Democratic Entanglements: Athenian Politics and the Practice of Philosophy, the author provides an extended argument against the 'canonical' portrayal of Plato as a 'virulent antidemocrat'.67 In Monoson's view, Plato's engagement with democracy as a form of rule is never a simple rejection, but rather a synthesis of repudiations of particular democratic practices and tendencies with appropriations of certain democratic values, all set within the context of Plato's own complicated relationship with Athenian democracy. While Monoson provides interesting analysis of many of Plato's dialogues and of the (pseudo-Platonic?) letters alongside the texts of other contemporary political theorists, orators, and historians, an extended examination of Plato's Statesman is conspicuously absent from her work. In a nearly 250 page book, about two and a half of these pages are dedicated to the Statesman. Monoson interprets Plato as claiming there

66 Jaeger, Theology, p. 140. Garani makes a similar point (Garani, 'Cosmological Oaths', p. 195).

67 S. S. Monoson, Plato's Democratic Entanglements: Athenian Politics and the Practice of Philosophy (Princeton: Princeton University Press, 2000), p. 3. 
that democracy is the 'best' of the 'likely-to-exist, flesh-and-blood regimes', which she also calls the 'imperfect, actually existing regimes'.68 Monoson suggests the Stranger's claim that democracies are 'least capable of perpetrating great evil' means that they afford the 'best protection against tyranny'69 Plato's critique in this discussion, Monoson claims, is leveled against the Athenians' obsession with their own legalism, which Plato implies is no real legal code at all. ${ }^{70}$ In this way, it seems to Monoson, Plato intertwines a moderate endorsement of democracy as a form of rule with a critique of the actually existing legal codes of Greek democratic states. For Monoson, we see in the Statesman 'Plato's appreciation of the difficulty of passing a final, single judgement on so complex a phenomenon as democratic government and ways of life.'71

Monoson assumes in this treatment that the only three forms of regime which Plato envisages as 'likely-to-exist' are the three lawless versions of democracy, oligarchy, and tyranny; in this light, democracy is the 'best' form of rule pragmatically possible. ${ }^{72}$ Monoson misinterprets the passage in question (i.e., 302b-303d). ${ }^{73}$ On a more fundamental level, however, Monoson misses the thorough-going rejection of democracy that Plato has woven into the fabric of the dialogue from the very beginning. The grounding assumption of the conversation between the Stranger and Young Socrates is that statesmanship is

68 Monoson, Democratic Entanglements, pp. 120-1.

69 Monoson, Democratic Entanglements, pp. 120-1.

70 Monoson, Democratic Entanglements, p. 122.

71 Monoson, Democratic Entanglements, p. 122.

72 Monoson, Democratic Entanglements, p. 121.

73 There are good reasons to wonder whether or not Plato believes the rule of the true statesman (one who possesses the 'kingly science') is a real pragmatic possibility: this 'seventh' form of rule, the Stranger says, is to be distinguished from the other six degenerate regimes 'as a god from men' (303b), which we might compare to Socrates' description of the ideal city in the Republic as a 'model laid up in heaven' (Republic 592b). Kahn gives a convincing argument that Plato did in fact consider the true statesman to be only an ideal possibility, of which the remaining, actual forms of government are just better or worse imitations (Kahn, Plato and the Post-Socratic Dialogue, pp. 231-5). However, contra Monoson, there is no indication in the text that we are meant to think of legal monarchy, aristocracy, and legal democracy as 'ideal' in this way. On the contrary, the ruling party in all six forms of lesser regimes are grouped together in distinction from the true statesman '... on the grounds that they are not statesmen but faction-makers', 'imitators', 'wizards', and 'the greatest sophists among the sophists' (303b-c). Indeed, the whole question of which among the 'incorrect regimes' (which includes again all six) are least and most difficult to live in presumes that they are all basically comparable as real pragmatic possibilities (cf. 302b-303b). Amongst these six possible forms of government, the two forms of democracy are cast precisely as a 'mean' or midpoint on the scale of best to worse regimes: legal democracy is the worst of the three legal (i.e., 'good') regimes, and lawless democracy is the least bad of the three lawless regimes (зоза-b). 
an epistēme and that the statesman is 'one among those who are knowledgeable' ( $\tau \hat{\omega} \nu$ ह̇ $\pi / \sigma \tau \eta \mu o ́ v \omega \nu)$ (258b; cf. 292b). This assumption is never questioned, always providing the touchstone in their search for the true statesman. But the constantly reiterated correlate to this claim is that of the essential illegitimacy of non-monarchic forms of rule, and especially of democratic rule. The only criterion for legitimacy of rulership that the Stranger will accept is the possession of kingly epistēme $(292 \mathrm{c})$, and three times he insists that a multitude of people could never obtain the art of political rule, which is always the purview of just one or some very few persons (292e-293a, 297b-c, 30oe). While the Stranger does make analogies between the political art and the other kinds of specialized arts in the cities (which are also only ever possessed by the very few), the basic claims that statesmanship is an epistēme and that democratic rule is inappropriate in principle are never argued for explicitly. This is surprising given the lengthy critique of specific Athenian democratic practices in the latter half of the dialogue (298a-30ob). Indeed, the Stranger presents for us a fuller picture of life in a democracy than he does of life under the reign of the true statesman, whose rule is described only in its essential act of weaving together moderate and courageous characters, and not at all in the particularities of the social structure present in this regime. ${ }^{74}$ Given the paramount importance of this claim about political epistēme and its possession by a one or few but never many, why does it seem the Stranger omits any explicit justification for it?

I suggest that the myth of the two ages offers a specific kind of support for the Stranger's prioritization of epistemic monarchy over other possible forms of rule. This support is persuasive rather than strictly argumentative, however, for the Stranger opts to set aside his dialectic with Young Socrates and to present his interlocutor (and we the readers) with a myth instead, one that he characterizes as a playful image and likeness $(268 \mathrm{~d}-\mathrm{e})$, yet also as one which has real causal-explanatory power and is especially fitting for the 'showing forth of the king' (26gb-c). Just as Homer, Hesiod, and the Presocratic cosmologists had used mythic-poetic discourse to make broader claims about the gods, the cosmos, and the sources of legitimate human authority, so the Stranger will deploy his own myth for the sake of persuading Young Socrates (and Plato's audience) regarding certain first principles of political cosmology. The myth operates as persuasive support for the Stranger's argument on two related registers: first, it establishes his cosmic monarchy precisely in and through its

74 We might compare, for instance, the lengthy descriptions of what kind of social structure is necessary for the true statesmanship of philosopher kings and queens to arise in the ideal city of the Republic. 
rejection of Empedocles' cosmic democracy; second, it establishes the necessarily mimetic relationship between our own political situation and the rule of the demiurge in the age of Kronos.

Section 1 of this paper has shown not only that the Stranger refers to Empedocles throughout his myth, but that the basic structure of the mythic cosmology described there is lifted directly from Empedocles' poem. When the Stranger insists then that the alternations in direction of rotation of the cosmos could never be due to the fact that 'some pair of opposite-minded gods turn it' (270a), the Stranger explicitly rejects the democratic foundation of Empedocles' cosmic cycles, in which the deities of Love and Strife cyclically exchange their offices and 'rule in turn'. The Stranger emphasizes the impropriety of democratic 'ruling in turn' in his description of the transition from the Age of Kronos to the Age of Zeus. The Age of Kronos is a time in which the demiurge rules the cosmos and its rotation (271d). When we enter the Age of Zeus, the god withdraws from the cosmos and his rule is, in a sense, passed off to the cosmos itself. After the cosmos reversed itself, it 'entered in an orderly way into its habitual course, itself exercising both care and control ( $\dot{\varepsilon} \pi \mu \dot{\varepsilon} \lambda \varepsilon\llcorner\alpha \nu$ xai xpátos) over the things within itself and over itself, and remembering the teaching of its craftsman and father as best it could' (273a-b). Later, we are told that 'it was prescribed for the cosmos to be the self-ruler of its own passage'

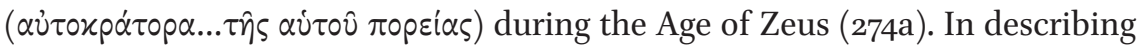
the Age of Zeus as a time in which the cosmos 'rules' itself, the Stranger again invites a comparison with Empedocles' rotations of office between Love and Strife: in a sense, the demiurge and then the cosmos itself rule the cosmos 'in turn'. Strictly speaking, however, the cosmos' self-rule is really no rule at all: it is the state of absence of true rule. The cosmos' self-rule is only the memory of the demiurge's true rule, which is inevitably forgotten as time goes by (273a-e). Without being grounded in the skill or art that the god possesses (which is

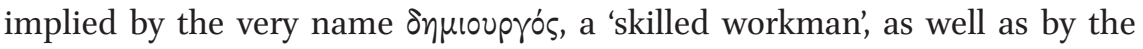
specific metaphors of shepherd, herdsman, and pilot) eventually 'the cosmos itself possesses and produces among the animals everything under the heavens that turns out to be harsh and unjust', i.e., the opposite of real governance (273b-c). One might thus pose the situation in the following way: lacking the true epistemme of the demiurge, the cosmos must rely on its increasingly faulty memory of his epistēmē, a memory which can never fully replicate this perfect rule and care but can only ever misrepresent the content of that epistēmé to a lesser or a greater degree. When the Stranger echoes Empedocles' idea of ruling the cosmos in turn in this way, he is thus also simultaneously 'correcting' that idea. If there were to be such cosmic cycles as Empedocles imagines, the Stranger seems to say, they could only ever be cycles of presence and absence 
of a single epistemic monarch, never the cycles of rotation in office proper to a democracy of equals. We can thus see here how Empedocles' cosmology is cited by the Stranger only to be rejected, not through an argumentative logos but through a persuasive, richly-textured muthos designed to rival Empedocles' own poetic imagination.

Finally, we need to briefly examine how the Stranger establishes the mimetic relation between the demiurgic rule in the Age of Kronos and the human political sphere. While it is never explicitly stated in the Statesman that human rulership should imitate the rule of the demiurge in the Age of Kronos, this idea is part and parcel of the logic of imitation at work in the myth of the two ages, and is confirmed by a passage from the Laws. As we have just noted, during the Age of Zeus the cosmos as a whole has an imitative relation to the rulership during the Age of Kronos through its memory of the 'teaching' of the demiurge (who has of course 'taught' only by immediate example, i.e., by offering a model for imitation) (273a-b). As a correlate to this imitation of demiurgic rule by the cosmos, the Stranger suggests that all the constituent parts of the cosmos, including human beings, imitate the condition of the cosmos itself during the Age of Zeus (i.e., they imitate its backwards-turning and lack of guidance from the god, which results in all the associated characteristics of the age) (273e-274a). For human beings, 'imitating and following along

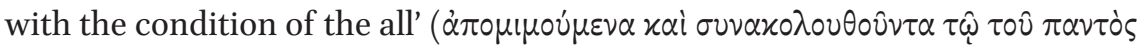
$\pi \alpha \theta \dot{\eta} \mu \alpha \tau \iota)(274 a)$ in this way entails ageing in the opposite direction, reproducing sexually rather than being born autochthonously, and becoming exposed to a dangerous, hostile world, which exposure directly entails the need for politics (274a-c). In the Age of Zeus, human beings have become, like the cosmos,

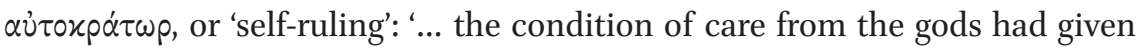
out, and humans themselves needed to take hold of the course of their lives and its care on their own, just like the whole cosmos, with which we, imitat-

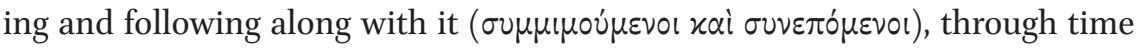

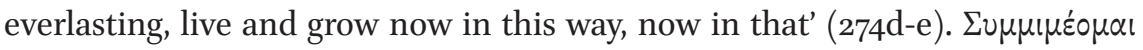
means not simply to imitate, but to 'join in imitating' (LSJ A.). ${ }^{75}$ Human beings do not just imitate the condition of the cosmos; we also join with the cosmos in imitating the demiurgic rule as much as is possible in our own attempts at selfrule. Because the cosmos imitates the demiurge in its own self-rule, and we imitate the cosmos in our own self-rule, when we attempt to govern ourselves we actually join the cosmos in imitating the demiurge; i.e., we try to 'remember'

75 Cp. the word $\sigma u \mu \mu \mu \eta \eta \tau$ 's in Paul's Letter to the Philippians 3.17: 'Be joint imitators of me, brothers, and behold those who walk around in this way, even as you have us as a model

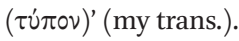


his rule, just as the cosmos does. ${ }^{76}$ In this way, both the cosmos as a whole and human beings in particular imitate the demiurge in their attempts at self-rule. Evidence confirming this interpretation can be found in a passage from Laws IV (713b-714a). ${ }^{77}$ Here the Athenian also invokes the Age of Kronos as a 'Golden Age' of plenty and prosperity, where the god sets the lesser divinities as rulers over human beings precisely because we cannot be properly 'self-ruling' ( $\alpha \dot{\tau} \tau o x p \dot{\alpha} \tau \omega \rho)$. On account of this deficiency, the best human governments can achieve is a mere imitation of the rule which establishes order in the Age of Kronos: '... it is said that in the time of Kronos there was a very happy rule and way of living, of which the best of current governments possesses an imitation ( $\mu^{\prime}(\mu \eta \mu \alpha)$ ' (Laws IV 713b; my trans.). The lesson of the myth, the Athenian explains, is that 'it is necessary for us to imitate $(\mu \mu \mu \varepsilon \hat{\sigma} \theta \alpha \mathrm{l})$ in every way possible the life said to have been led under Kronos ...' (Laws IV 713e; my trans.).

Now we are in a position to fully appreciate how the myth undergirds the overall political argument of the Statesman. If the cosmos is structured not as an Empedoclean democracy but as a monarchy, and if human governance should mimetically reflect this rule, then the best human regime is necessarily an epistemic monarchy or as close of an approximation to this as is practically possible. We have seen how Empedocles could stand for Plato as an exemplar of the popular Greek trope which envisions a macro-micro level similarity between cosmos and polis as well as the normative and political implications that this relationship carries. In the Statesman, Plato appropriates Empedocles' cosmic cycles while rejecting their democratic valence, 'improving' them by replacing Empedocles' democratic rotation of rule with his own cycles of the presence and absence of a supreme cosmic monarch. Playing on the Greek cosmological-political trope by replacing Empedocles' cosmic democracy with his own version of a mythical cosmic monarchy, Plato suggests a kind of mythic 'argument': (1) In a previous age, the cosmos was ruled by a monarch possessing epistēme (not by equal constituents in a cosmic democracy); (2) In our current age, the correct form of human political rule

76 An important caveat: proper human imitation of the demiurge does not imply becoming a 'shepherd' in the way the demiurge is our shepherd in the Age of Kronos. Assuming a human being could be a 'shepherd' in a way analogous to the demiurge is precisely the 'great error' the myth is ostensibly designed to correct (cf. 274e-275a). Proper imitation of the demiurge would be rather enacting the right kind of 'tending' or 'caring' of the human flock which is possible by one human being over others. This is still imitation of the demiurgic rule, though, for it acts precisely as a prosthetic for the care that would otherwise have been provided by the gods in the Age of Kronos.

77 Cf. Kahn's interpretation of the passage: Kahn, Plato and the Post-Socratic Dialogue, pp. 233-4. 
should imitate that absent rule; (3) Therefore, the correct form of human political rule is rule by a monarch possessing epistēme (not by equal constituents in a human democracy). ${ }^{78}$ Thus, it is precisely Plato's simultaneous appropriation and rejection of Empedocles' political cosmology that supports the adoption of sovereign episteme $\bar{e}$ as the basic criterion in the search for the statesman, an epistème that could never be the possession of a democratic hoi polloi. The logic of this 'argument' is readily available to Plato, for it is simply a repetition of the well-established cosmo-political symmetry that Empedocles and many others envision. What is needed to 'correct' the tradition that conceives this symmetry in terms of equalitarian politics is precisely a new mythic discourse with which to understand the place of the human being in the cosmos. And this is precisely what the Stranger offers us in the myth of the two ages.

In a final pièce de résistance, the Stranger suggests at the very closing of the Statesman that, upon completing the 'smooth and well-woven web' of moderate and courageous souls in the city, the culminating act of statecraft will be 'always to turn over to them in common the offices in the city' (310e-311a). We see here a last blow against cosmic and human democracies, for the Stranger argues that a genuine sharing of offices and of rule in the city is only possible under the epistemic monarchy of the true statesman. A sign of the polis' tightly woven social fabric, this best city will be one in which the offices of rulership are shared alike amongst moderate and courageous souls, but always under the watchful eye of the monarch who possesses kingly epistēme (311a). Far from showing us Plato's ambiguous relationship to rule of the many, the Statesman thus exhibits the staunchest rejection of the appropriateness of democracy for our own political situation and for the cosmos as a whole. ${ }^{79}$

$7^{8}$ Posed in this way, we can see why Kahn is drawn to describing the myth as functioning like a 'premise' in the argument of the dialogue.

79 I am deeply indebted to Sean D. Kirkland and Michael Naas for their comments on early drafts of this paper, as well as to two anonymous referees for their extensive suggestions throughout. 